University of Nebraska - Lincoln

DigitalCommons@University of Nebraska - Lincoln

U.S. Environmental Protection Agency Papers

U.S. Environmental Protection Agency

2007

Discovering Price in All the Wrong Places: The Work of

Commodity Definition and Price under Neoliberal Environmental

Policy

Morgan Robertson

U.S. Environmental Protection Agency, robertson.morgan@epa.gov

Follow this and additional works at: https://digitalcommons.unl.edu/usepapapers

Robertson, Morgan, "Discovering Price in All the Wrong Places: The Work of Commodity Definition and Price under Neoliberal Environmental Policy" (2007). U.S. Environmental Protection Agency Papers. 150. https://digitalcommons.unl.edu/usepapapers/150

This Article is brought to you for free and open access by the U.S. Environmental Protection Agency at DigitalCommons@University of Nebraska - Lincoln. It has been accepted for inclusion in U.S. Environmental Protection Agency Papers by an authorized administrator of DigitalCommons@University of Nebraska - Lincoln. 


\title{
Discovering Price in All the Wrong Places: The Work of Commodity Definition and Price under Neoliberal Environmental Policy
}

\author{
Morgan Robertson \\ US Environmental Protection Agency, Office of Water, Wetlands Division, \\ Washington, DC, USA; \\ robertson.morgan@epa.gov
}

\begin{abstract}
Price plays a unique role in neoliberal economic theory, quantifying value and providing markets with the information needed to produce equilibrium conditions and optimal social welfare. While the role of price is clear, the mechanisms by which prices are discovered, and by which the commodities they value are defined, are left obscure in neoliberal theory. Automatic price discovery, and self-evident commodity identities, are assumed. Observation of newly created markets in ecosystem services suggests that this is a moment of significant tension within neoliberal practice, as potential market participants seek guidance from the state on appropriate commodity measures and pricing practices. Bureaucrats and economists, following the neoliberal preference for governance over government, turn the task back onto civil society. The invocation of abstract rules, instead of the formulation of practical guidance, by policymakers means that the neoliberal marketization of non-market public goods is a contingent and sometimes rudderless task for those who must make markets work on the ground. This presents many opportunities for constructive engagement on the part of geographers and other critics of neoliberal strategy.
\end{abstract}

Keywords: Ecosystem services, neoliberal economics, price discovery, wetland banking, water quality trading, commodification of nature.

If you think prices come from markets, then you think milk comes from bottles. (Dan Bromley ${ }^{1}$ )

\section{Introduction}

On a hot July day in Washington, DC in 2005, a forum of environmental policy-makers and private-sector stakeholders convened at the Carnegie Endowment for International Peace to begin building a new market. Over the past decade, the US Environmental Protection Agency (EPA) and the US Department of Agriculture (USDA) have made increasingly determined attempts to create the necessary institutional support for trading water quality credits. In this, they have been buoyed by the success of other "regulatory markets" such as those for air pollution and wetlands, and their efforts have recently reached a new pitch with three 
major workshops in 2005-2006 and the issuance of a joint memorandum on the subject (EPA and USDA 2006). And yet, to the growing frustration of headquarters staff and managers, no market has emerged. The urgency of the matter comes from the fact that the 1977 Clean Water Act (CWA) forbids facilities from discharging pollutants into water without a permit; obtaining such a permit has come to entail such delay and technological sophistication that overwhelming political pressure now bears on the project of making CWA compliance cheaper and faster. Since the late 1980 s, the efficiency of markets at finding least-cost solutions has been the main rubric of American environmental policy reform (EPA EITF 1991). At the Carnegie conference, after some introductory remarks by a political appointee touching on the nonpartisan and inevitable nature of market-based environmental policy and the power of citizens in free markets to effect beneficial social change, a University of Maryland economist stood up to say what nobody wanted to hear.

He announced a profound skepticism about the ability of strictly free markets to meet environmental regulatory goals, such as the goal of limiting contaminants in rivers and streams. His skepticism stemmed from the fact that, as has been pointed out by many resource economists, demand and supply in such regulatory markets are entirely controlledentirely created - by regulatory directives rather than the utility functions of individual market participants. The supply of the commodity "water quality", he noted, is a function of the regulatory standards applied to the measurement of improvements in water quality: "You can always make the supply and demand curves cross if you can get the regulator to water down the scoring criteria". ${ }^{2}$ Crucially, and for maximum rhetorical effect, his critique was aimed specifically at that icon of equilibrium economics, the supply/demand curve. Suggesting that the market-clearing price produced by this curve is not the product of exogenous human desires constituted an outright attack on the two fundamental theorems of welfare economics ${ }^{3}$ which underpin neoliberal thinking, and quick action was needed to save the day for market enthusiasts. Fortunately, another political appointee was on hand, and leapt quickly up to offer the simple bromide of Say's Law: supply will create its own sufficient demand. As this was considered self-evidently true, it cleared the furrowed brows of the assembled experts.

Say's Law, in its "pure" form (a form never actually articulated by the $19^{\text {th }}$-century economist Jean-Baptiste Say; Rosenberg 1992) serves as a sort of narrative underpinning for the centrality of equilibrium analysis and the price theory of value in modern mainstream economics. ${ }^{4}$ It is one of those delicious omphalic credos that lie at the heart of many a sprawling research paradigm. While it is mainly of historical interest to most economists, its simplicity allows it to persist in popular rhetoric as an ideological invocation, entreating a level of demand to issue forth from the black box of individual utility within us all sufficient to 
consume available supply. Leon Walras' two theorems of 1874, elegantly mathematized in the Arrow-Debreu proof of 1953 (Mirowski 2001:268), expanded upon Say's Law and required price to be the mechanism which coordinates this balance between demand and supply to the point of Pareto-optimality, where no further increase in net social welfare is possible through market exchange (Rosenberg 1992:99). When harnessed to the postwar neoclassical economists' methodological commitment to individualism and rational actors, the macroeconomic imperatives of Say and Walras were brought down to the scale of the mind of each market agent.

The stakes are thus very high, as the theoretical rationale for neoliberal capitalism has been erected on individual rationality and Walrasian equilibrium. For Walras' equilibrium theory to work, price signals must serve as the information that allows rational actors in a free market to take stock of their own desires against the resources needed to satisfy them. Thus price is theorized in classical liberal economics as the purest expression of value. For mainstream economists, ${ }^{5}$ achieving social welfare becomes, in part, a process of facilitating accurate price discovery, of providing rational market actors with enough and sufficiently accurate information to respond to price signals. Of the many lines of criticism which come to bear on this claim, one in particular points out that Walras' and Say's principles apply only to markets in equilibrium, which is a condition that is almost never observed. Hodgson notes the cop-out, calling Walras' solution a deux ex machina which is premised on a forgetting of history, experience, and common sense about price behavior: "In neoclassical theory the only kind of price norm is the ex post equilibrium price. It is presumed to be formed after an extensive process of market adjustment and price signaling in logical rather than historical time" (1988:182). As the very name "discovery" implies, it is expected to emerge fully-formed from its cache.

But what about new markets? Markets where there is not only no extended history of price discovery, but in which the very identity of the commodity requiring a price is still in flux? This paper is concerned with observing the emergence of commodity identity and price in such a market - prices that, we are assured after-the-fact by the partisan representatives of the neoliberal capitalist state, emerged from the unmediated expression of human desires. While these are quite specialized markets that are called forth to achieve the regulatory goals of the CWA, they may also be similar to the nascent markets that are arguably commonplace all around us, but about which the dominant theorems driving economic research programs have virtually nothing to say. Observing the difficult birth of one such market, I found Say's Law pulled into service to dispel anxiety rather than to explain observed data: we need not fear for the future of a market in tradable water quality credits, for Say's Law tells us that buyers will appear if credits are produced. And although the 
theorems of welfare economics were not named as such in these forums (presumably due to the inside-the-beltway polysemy of "welfare"), their messages were constantly invoked to reassure us that the market price for credits will coordinate supply and demand such that optimal social welfare is achieved.

The point is not that facile misreadings of Say and Walras do injustice to the original thinkers themselves, but rather that such invocations are the ideological wheels on which neoliberal capitalism achieves its expansionist dynamic. This tendency on the part of market advocates is particularly clear in the recent effort to bootstrap "ecosystem services" markets into existence (Costanza et al 1997; Daily 1997; Daily and Ellison 2002; EPA 2003; McAfee 1999; NRC 2005; Turner et al 2003). By casting elements of the environment as "services" which provide value to human societies, they hope to stimulate environmental conservation through privatization and ownership. Following a line of logic that runs from Locke through Walras to Coase, the main thrust of these efforts has been to define new elements of the environment as property, distribute the rights to its ownership, and hope that markets and prices follow as rain follows the plow. There is every reason to suspect, however, that this latest round of the commodification of nature will experience the same contradictions as any attempt to establish markets in what Karl Polanyi (1944) termed "fictitious commodities" (Castree 1995, 2002; J O’Connor 1994; M O’Connor 1994).

But my aim here is not to fire a theoretical broadside concerning the fundamental instabilities and injuries of capital; the claim that neoliberal economic policy makes unrealistic assumptions is by now heavily belabored and exhaustively documented. My wish here is instead to observe neoliberal capitalism in situ in the context of a specific engagement with environmental policy, to show how these precepts force actual market participants into logical conundra, and how they do or do not work themselves out. The creation of new markets in novel kinds of commodities is a moment of particular importance in the definition of new kinds of property and the expansion of neoliberal capitalism, and I examine this moment through an ethnographic approach to the definition of tradable property in environmental services, and the measure of these properties through price. The material in this paper was gathered through interviews with the producers, consumers, and regulators of regional markets in wetland credits and of the prospective markets in water quality credits, as well as through participation in three national workshops on the subject of challenges to the development of water quality markets.

Work documenting the on-the-ground overcoming (or not) of the contradictions of capitalism will lead to finer-grained understandings, and can provide a tonic against the depressing tendency to see capital as unitary and omnipotent (Gibson-Graham 1993; McAfee 2003). Bakker (2005), for example, provides an excellent taxonomy in the course 
of suggesting that much of what we refer to using the blanket term "commodification of nature" actually consists of three interrelated moments: privatization (efforts to change ownership), commercialization (efforts to introduce efficiency and standardize production and measurement) and commodification (efforts to construct a market and make products fungible). Throughout this paper, it will be possible to observe these processes as overlapping, at times abandoned, and not understood as separate by the participants. It is also significant that participants in these debates do not even perceive these consistently as tasks to be accomplished at all: specifically, the market builders assume the automatic achievement of two important tasks which are actually an expansive and time-consuming task of institutional construction: the definition of the commodity and the discovery of price (which might fit into Bakker's typology as components of commercialization and commodification, respectively). The work of achieving these two tasks was actually eminently visible at the table in the July workshop, but to formally recognize such work would be to undercut the conceptual apparatus that sustains neoliberalism and minimizes the role of government. A hallmark of neoliberal policy is that it seeks to move outside of the formal apparatus of the state-castigated as ossified and insufficiently democratic-to achieve policy aims through the institutions of civil society (Amin and Thrift 1995; Peck and Tickell 2002) and an effective, direct and inherently democratic free market (Huber 1999). But, in practice, efforts to develop neoliberal environmental policy have led to endless numbers of "stakeholder forums", in which to achieve the outcome and effect of market-led environmental governance, we had to avert our eyes from the actual acts of government occurring at a table crowded with bureaucrats.

\section{Say What? New Commodities}

I will focus my discussion on two developing markets: a planned market in water quality credits, and a young but extant market in wetland credits. Both have been promoted heavily by recent Administrations as privatesector solutions to the regulatory burdens imposed by the CWA of 1972 (EPA 2003; USACOE and EPA 2006; WHOEP 1993).

Wetland credits have been created and sold by entrepreneurial providers since 1992, in response to the CWA requirement that wetland impacts be compensated for by the party applying for a permit to fill wetlands; compensation usually consists of an equal or greater acreage of restored or created wetlands. Throughout the 1980s, nearly all compensation sites were constructed by the permit holder, and the highly uneven environmental results are a matter of record (NRC 2001). Since the early 1990s, however, regulators have been encouraging the development of both public and private "wetland banks", large pre-constructed acreages of restored wetland, which can be certified as containing a 
certain number of credits for sale to permit holders. Purchase of such credits satisfies permittees' CWA obligations. Wetland banks, although ecologically problematic in many ways, provide greater assurance of ultimate regulatory success than permittee-built compensation sites; banking has received some support among the environmental and regulatory community despite ingrained suspicion that wetland bank entrepreneurs "make a profit" off of wetland destruction (ELI 2002; Sibbing 2005; SWS 2005). Banks also have been specifically promoted by both the Clinton and GW Bush administrations as a market-led way to reduce the cost of regulatory burdens (EPA 2005; USACOE et al 1995). There are currently several hundred entrepreneurial providers of wetland credits around the nation, and price-based competition among them is said to exist in many areas. They have formed a national lobby (http://www.mitigationbanking.com) and have become quite influential as a self-described pro-environment constituent within the larger land development industry.

In the case of water quality trading, the limits placed on point-source (piped) inputs of pollutants into rivers have successfully reduced the level of pollutants entering the nation's waters, but the development of new polluting facilities challenges these limits. Rather than demanding ever-increasing levels of pollution control (which faces technical barriers and achieves diminishing environmental returns past a certain point), regulators have attempted to arrange for trades to occur between pointsource polluters and the large population of unregulated "non-pointsource" polluters ${ }^{6}$, mainly agricultural operations, which can cheaply and easily reduce their contribution to water pollution. Participation in such markets in the role of "credit providers" is voluntary on the part of farmers. However, it is usually less expensive for farmers to reduce pollutant runoff from their fields into rivers than it is for, say, an urban water treatment plant to squeeze another increment of pollutant reduction out of an already very clean process. Market enthusiasts, always alert to such gaping differences in marginal cost, have argued that allowing polluters to buy pollution reduction credits from farmers can dramatically lower the cost of compliance for point-source polluters. An urban sewage treatment plant can buy a reduction in pounds of nitrogen much more cheaply from a farmer willing to change tillage practices than it can by retrofitting its system once again.

Given the obvious economic efficiency, it has stumped regulators and economists alike that, after nearly a decade of promotion by the EPA, a market in water quality trading (WQT) has failed to emerge. Hoping to inject a note of practical achievements on-the-ground into the prospects for WQT, the organizers of the Carnegie conference in Washington offered a chance for WQT to "learn from" the established success of wetland bank credit markets. The ensuing debate (as well as the discussions dominating a follow-up forum in Chicago in February of 
2006; EPA ORD forthcoming) was strong on highly abstract questions of commodity definition and the invocation of economic platitudes, but could not come to grips with specific interventions. To the jaundiced eye of institutional and Marxist economics, it was a theatre demonstrating the consequences of neoliberal economics' formal blindness to the complexity of social structures which underlie and support markets. The forums on WQT were so thick with ad hoc and unsteady retellings of the fundamentals of welfare economics that participants were reduced to invoking "free-market-based, you know, supply-and-demand, capitalism, whatever you want to call it". ${ }^{7}$ Having been assured that Say's Law would provide demand for, and accurately price, whatever WQT credits were supplied, regulators and entrepreneurs found themselves unable to comfortably specify and justify the actual interventions required to establish a market.

\section{Demand Will Appear ... But For What?}

How do we [plan a production strategy] in Water Quality Trading? We can't do this! The market will do this. If you've got your command-andcontrol hat on, take it off, put it in the back. (Tony Prato, economist ${ }^{8}$ )

What you have is a commodity that you can't really observe. (Jim Shortle, agricultural economist ${ }^{9}$ )

Whereas the Walrasian "auctioneer" (an avatar of the market who plays a coordinating role in connecting buyers with sellers) is theoretically a costless and effortless creation (Boyer 1997), agreement on the actual coordinating institutions of water quality trading has proven to be intractable. Prato's epigram above suggests the tension in the room: on the one hand, the scientists and bureaucrats were admonished to be humble in the face of the power of the market to automatically discover appropriate products, prices, and production strategies. On the other hand, why had they been assembled if not to provide precisely such guidance? The paralysis this produced was palpable.

In this section I want to analyze one institution-building aspect of the debate which unfolded over the two conferences: what is the new property, the commodity being traded? "Water quality", said the title of the forum, but what is it and how is it measured? Considerable energetic debate explored the various ways of defining and measuring the commodity, but each potential resolution posed obstacles.

In a WQT market, someone who makes efforts that improve water quality can receive credit for those efforts, and then sell that credit to another party who wishes to degrade water quality in the same waterway to the same degree. It is therefore not a way to reduce pollution, but rather a way to allow the operation of comparative advantage to lower costs. Typically, an urban water treatment plant will purchase such credits from 
upstream farmers, so that the treatment plant may exceed the nitrogen limits imposed on them by the EPA. Such farmers may take measures (known as "best management practices", or BMPs), such as conservation tillage, which are known to reduce the runoff of nitrogen from farm fields.

Crucial questions arise immediately. Must the farmer's actions actually produce a measurable reduction in nitrogen loads downstream, or is installation of the BMPs sufficient to generate credit? How is an improvement to be certified and warranted? How can a regulatory agency document that pollution reductions are due to a farmer's BMP, given the dynamism of the entire landscape in contributing nitrogen to that stream? The answers to such measurement questions give shape to the commodity, and the lack of clear answers means that the commodity has a somewhat ethereal existence. For example, even if the nitrogen levels are measured a mile downstream from the farmer's field, the specific change produced by the farmer's BMPs will be hard to detect among the "noise" of other changes in the landscape. Such difficulties stimulated participants to find proxy measures that bypassed highly uncertain measurement methods. But if a WQT credit is not measured as a quantity of contaminant abatement downstream of the credit provider's facility, what $i$ s the identity of the commodity? Many answers were offered.

\section{Functional Lift}

Ecologists at the conference claimed that the most direct and scientific way of measuring the WQT commodity is as an increment of change at the site where abatement activities are carried out. This is often termed "functional lift"; that is, the credit represents the increase in environmental quality or function (in terms of decreased nitrogen contribution to a waterway near the farmer's land) compared with what the farmer's land would have contributed without the abatement activities (the "baseline"). Although this is a common-sensical method suggested by many at the conference, immense problems of measurement present themselves to conceiving of the commodity in this way. Firstly, ecologists objected that the baseline is a speculative condition that would change over time in unknowable ways. They also questioned the ability to quantify the lift provided by various BMPs. As ecologists described the intensive monitoring regime necessary to defensibly document "lift", economists and regulators began to protest that such certainty would be too time- and labor-intensive to achieve. Their objections were revealing. Economists viewed such information gathering as excessive because the credit purchaser's utility is fulfilled without knowing the exact ecological state of the abatement measure. Regulators viewed such information gathering as excessive because it would provide more data than the regulatory staff could absorb in making a determination that the farmer is in compliance. 


\section{Regulatory Relief}

Some conference participants referred to the commodity as a unit of regulatory relief, measurable as "velocity through a regulatory system". This definition has the advantage of complete frankness: both credit producers and credit purchasers are completely disinterested in the ecological outcomes of their transactions. Credit purchasers desire only the rapid resolution of their encounter with the CWA permit program. The mercenary nature of this definition makes some PR-conscious market enthusiasts nervous, and has stimulated economists to use game theory to model markets where utility of both buyers and sellers is maximized by collaborating to force the market regulators to lower certification standards (King and Kuch 2003). That is, if credit producers can make subpar credits cheaply, and sell them cheaply to purchasers, without triggering regulatory compliance measures, a market mechanism will function admirably while failing to produce improved environmental conditions.

\section{Liability}

A similar way of speaking about the commodity—but one that didn't trigger such unease-was to refer to it as a purchasable transfer of liability. That is, WQT credit providers take on, for a fee, the responsibility of and liability for complying with the effluent limitations that a credit purchaser wishes to exceed. While a market in "regulatory relief" remains metaphorical, a market in transferable liability has clear precedent in the insurance and financial bonding industries. However, a commodity measured in "liability" has no closer a relationship to the ecological status of abatement sites than one measured in "regulatory relief", and faced similar strong opposition from environmentalist and scientific interest groups.

\section{Time}

The purpose of the Carnegie forum was for WQT to absorb the lessons of the successful wetland credit market, but a crucial difference emerged on the issue of commodity measurement. WQT credits, as property, have a temporal dimension and can expire: the purchase of lift, relief or liability is tied to the duration of the purchaser's need to exceed their own effluent limitations and thus must be expressed in units of lift/time, relief/time and liability/time, rather than just lift, relief or liability. Once the purchaser no longer needs the abatement, it can be bought by another purchaser. Wetland credits, by contrast, are sold to permanently compensate for impacts to wetlands. This essential difference prompted one wetland credit producer to repeatedly claim, "I am in the graveyard business!": like the sale of a graveyard plot, the sale of his 
commodity permanently retires its value. As fundamental as this difference is, it was not immediately appreciated by conference participants that adding a temporal dimension to the definition of the commodity might call for entirely different production strategies and initial rights allocations.

\section{Probability}

A fifth way in which the potential commodity was defined was in terms of the probability of its existence. Given the overwhelming problems of measurement and confirmation posed by ground-verifying the existence of hundreds (or thousands) of water quality abatement sites, on scattered farmsteads, prototype markets in water quality such as the South Nation River watershed in Ontario ${ }^{10}$ and the Greater Miami River Watershed Water Quality Trading Program in Ohio ${ }^{11}$ have encouraged the use of remote sensing and random sampling to certify the existence of the commodity. This gives the commodity a distinctly stochastic definition; in the Carnegie forum, it was proposed by an economist that perhaps $10 \%$ of all WQT credit-generating sites should be evaluated per year, and that the statistical Law of Large Numbers will guarantee that, in the aggregate, sufficient water quality abatement would be achieved to meet regulatory requirements. ${ }^{12}$ This use of the Law of Large Numbers, much like the use of Say's Law, ventured far beyond the limits imposed by the Law's formal assumptions and served mainly to attempt closure of the debate on the nature of the commodity.

How far this babel of commodity definitions is from Say's confident predictions of demand! It is undeniably a little silly to be beating up on Say at this point in history, but his prominent invocation suggests that he cannot rest and must be continually invoked to first settle, and then obliterate the memory of, such debates. WQT is proving to be a tough case for equilibrium economics, however, and the nature of the three-way chicken-and-egg debate is now clear: of the institutional perspectives represented at the table, neither bureaucrats nor capitalists nor scientists wanted to claim responsibility for making the hard foundational choices about what would constitute the object of utility, desire and property in this market. More precisely, bureaucrats and scientists tossed the hot potato between them, while economists insisted that the game is futile. Representatives of the regulatory state insisted, in varying language, that "the science will tell us what is required to certify that water quality improvements are real and therefore fungible". Scientists responded with equal vigor that "we could tell you a universe of things about water quality, but only regulation can place parameters on the discussion such that our information is useful". Finally, economists insist that such parameterizing can only be done by the invisible hand: the market is capable of producing only optimal social welfare, and neither 
science nor policy can engineer its results without destroying its identity as a market. 13

\section{Let's Talk About Price}

The fiction of a minimalist state is belied by the reality of the state as entrepreneur, banker, distorter of prices, capitalist policeman and promoter of capitalist networks. (Michael Watts 1994:380)

The prospective market in WQT credits is at such a nascent stage that debates such as the one outlined above do not yet show a trajectory toward resolution. Lacking even a stable commodity identity, a whole suite of follow-on questions cannot even be asked, making the invocation of Say's Law particularly premature. Let us now look at the wetland banking market, which is slightly further down the road and has (however contingently) resolved the debate over the identity of the property being traded. Banking provides a window on the next struggle: the effort to discover a market-clearing price. This is really the moment where Say's Law is supposed to earn its keep, where the automatic, effortless coordination of supply and demand, with only the lightest of guidance from a minimalist state, is supposed to produce a market-clearing price that fully reflects the value of the commodity to society. Experience tells the skeptical observer that a great deal of work will be required, and then effaced, in achieving this. It is therefore interesting to examine how economists talk about price in wetland banking markets, in comparison with how the banking entrepreneurs themselves actually set price, and explain that action to themselves and others.

\section{Economic Theorists}

it does not matter whether the economic system is named capitalist or socialist. It all amounts to whether the pricing policy is based on marginalist principals, which will lead to the optimum allocation of resources. (Tjalling Koopmans 1945, in Mirowski 2001:244)

Economists who work on wetland credit markets acknowledge that these markets are not self-regulating, and that they are fully dependent on strong state regulatory power in the generation of all demand and supply (King and Herbert 1997; Oates 2006; Scodari and Shabman 1995). And yet, agentless price discovery surfaces repeatedly in their analysis as the social-welfare-maximizing tool which justifies market-based policies. To be fair, this is the only acceptable way within mainstream economics to theorize the existence of prices for wetland credits - and they do exist, apparently negotiated between buyer and seller with no interference from regulators, a fact which intoxicates the most cautious neoliberal economist. A world of acknowledged evidence that the market runs on regulation and not price is thrown aside. 
Resource economists' enthusiasm over the wetland credit market's ability to produce prices is understandable. The history of theoretical writing on market environmentalism amounts to a sustained lamentation over the lack of prices which would give market participants enough information to engage in rational choices. Hahn in 1983 described the fundamental task in constructing an ecosystem service market as a question of eliciting price: "the basic objectives are to design a market that will elicit a price signal, induce efficient abatement decisions and satisfy considerations of equity" (88). Likewise, Shabman and Batie expressed cynicism about the conservation efforts of the 1970s because of the lack of price:

Because property rights for these ecological services are ill-defined, and because costs of transacting between owners of wetlands and beneficiaries of ecological services are high, there are no markets where owners of wetlands can sell ecological services to willing buyers. As a result, the market price for wetlands will not reflect the value of these ecological services. (Shabman and Batie 1980:3)

There has thus been considerable celebration that the actual value of wetland ecosystems had finally been revealed in wetland banking markets:

The value of a [wetland] credit can be determined by looking at costs faced by an applicant that has no credits ... An applicant will pay at least [the option cost] for available credits. The holder of the credits knows what it costs to produce those credits. If the applicant who needs the credits offers the holder of the credits an acceptable rate of return, a sale will be made. Once a sale has occurred, a value has been determined. (Zagata 1992)

The tantalizing existence of prices did not cause economists to forget the complicated regulatory architecture that created supply and demand, but it did cause them to make rather unguarded and optimistic predictions. The following restatement of the welfare economics credo announced, in a very widely cited policy work on wetland banking, that wetland credit commodities could be expected to behave as any other commodity: "it is the interaction of supply and demand within each region that establishes credit prices and the number of credits needing to be supplied" (Shabman, Scodari and King 1994). This statement is followed by an extended narrative scenario in which economically rational actors arrive at different prices given different initial distribution of rights. It is a modern and specific retelling of the two theorems of welfare economics accompanied, in a subsequent report from the same series, by a diagram that achieves much the same effect (Figure 1). "Yes", it seems to say, "there are a multitude of contingent and inconvenient factors that may interfere with the ability of the market mechanism to deliver the 


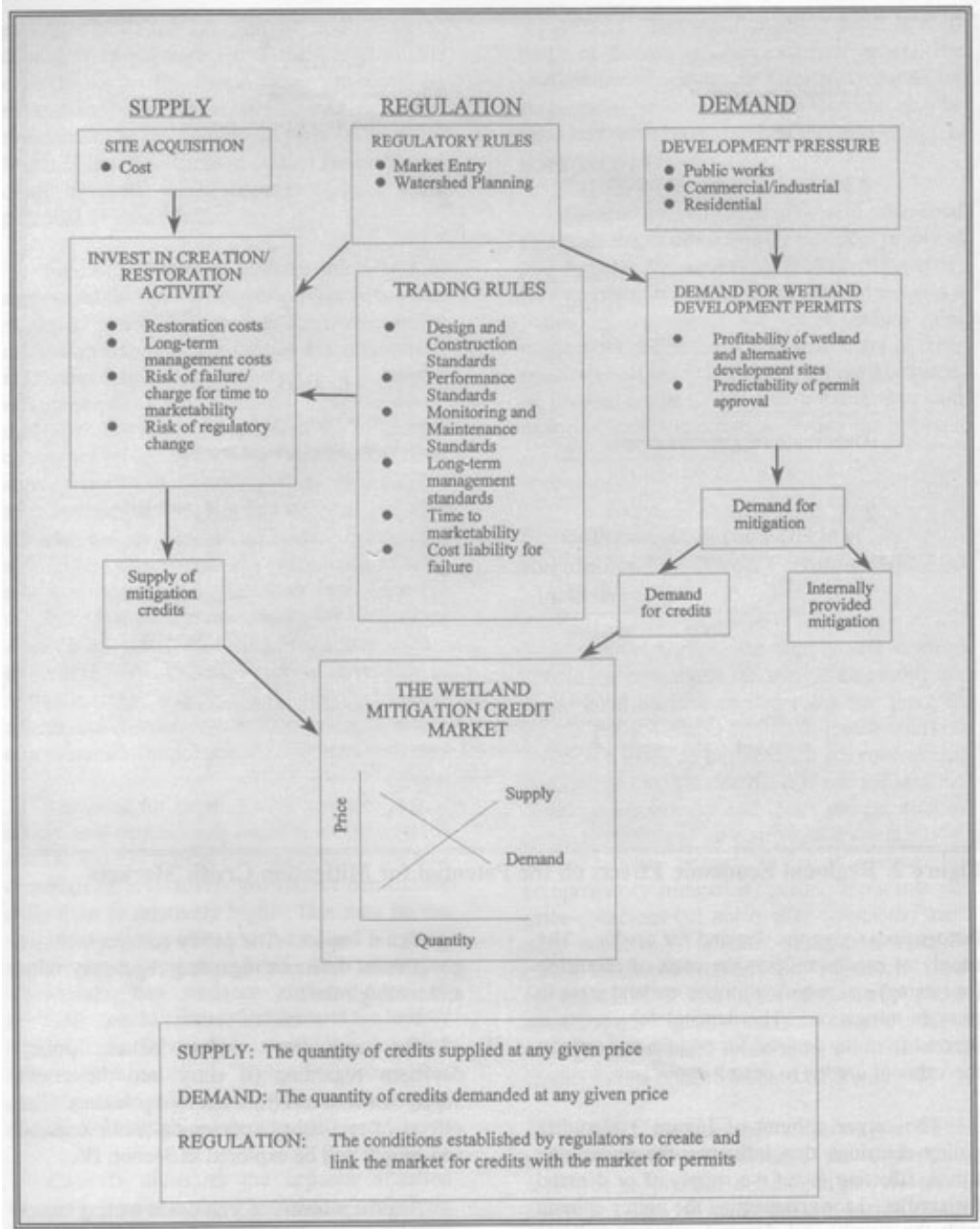

Figure 1: Diagram of the operation of a wetland credit market (source: Shabman, Scodari and King 1996)

promised maximal social welfare". But they are graphically dismissed. As if the Hudson River school had tackled a box-and-arrow diagram, the wilderness of regulatory and non-market influences gives way to the ordered and civilized simplicity of the supply and demand curve: at the bottom of the diagram - to which all boxes point their arrows - sits our old friend the market-clearing price.

In more earthbound moments, economists talk frankly about the potential for perverse and persistent regulatory policies to interfere in the 
price mechanism, such that it may inevitably produce irrational results. Such problems had been predicted since the early observations of price in air pollution credit markets in the early 1980s:

there are many cases where exchanges occur without money passing hands; where exchanges occur but they are not freely entered into; where exchanges are so constrained by institutional rules that it would be dubious to infer that the terms were satisfactory; and where imperfections in the conditions of exchange would lead us to conclude that the price ratios do not reflect a corporate social judgments about values. Each of these cases gives rise to deficiencies in the use of existing price data as the basis of evaluation of input or outputs. (Shabman and Batie 1980:5)

This concern is familiar in the wetland credit market of 2006, but takes on an urgently pragmatic tone: now that we finally have the capacity to generate prices, economists say, the goal of policy must be to ensure that regulatory and non-market factors don't interfere with the generation of accurate price signals. All such interference, by definition, is exogenous to the market and to the intimate dance by which buyer and seller determine price. Left alone, this process will be rational and generate the promised social welfare. Price distortions, and therefore market failures, are to be explained in terms of regulatory interference, spatial monopolies, or inelastic demand-anything but problems with the fundamental capacity of a buyer to recognize a manufactured commodity as an object that increases his or her utility, and to purchase it at a price which reflects that utility with crystalline accuracy. In fact, the pellucid transparency of the unfettered market is frequently invoked in both WQT and wetland banking forums: "The transparency of the market helps create the clarity that is needed", and requires only "that a willing buyer and a willing seller know what they're buying, what the price is, and that they can count on the product". ${ }^{14}$ The various fetters placed on markets, and problems in defining commodities and discovering prices, can create the impression of hopeless entanglement with extra-market social forces. Nevertheless,

Before we submit to this incubus of complexity, however, we might seek comfort in the reflection that the great virtue of a pricing system is that it solves, avoids, mediates, or somehow manages to dispel, all sorts of complexities, particularly those that arise from various interdependencies between uses and users of goods. (Dales 1968: 792)

Belief in the market-clearing price can, in other words, be tested, wrestled with, raged against, and can generate schisms, but will in the end reward faith with grace. 


\section{Entrepreneurial Bankers}

This optimism is why, in dispensing advice to his fellow wetland bank entrepreneurs, Michael Rolband can cast the basic challenge of banking in terms of price:

As for any product, classical supply/demand relationships will determine the appropriate price of mitigation credits ... The fundamental economic test that a wetland bank must meet is the ability to sell credits at a price that exceeds expected costs and investor return requirements. (Rolband et al 2000:203-210)

As a national figure in the industry, it is Rolband's prerogative to invoke such abstractions from the pulpit of a major policy publication. But his advice offers little practical guidance, and few bankers join him in these sentiments when discussing the task of setting price in actual transactions. In asking entrepreneurial bankers what their actual practice is in setting price, I am doing something deeply irrational by the lights of mainstream economic theorists. Since the Chicago-school economists led by Milton Friedman dismissed the need for empirical verification of the models of quantitative economics, the investigation of actual thoughts and opinions of market participants have been considered somewhat quaint and certainly irrelevant in the face of nearly universal acceptance of aggregate rationality (Mäki 2000; Mirowski 2001:198; Rosenberg 1992:88). Asking individuals for their personal justifications of their own actions is thus akin to asking the roulette ball why it fell on 33 .

Nonetheless, if we fail to insist that the way people think about, talk about, and act out the supposed iron imperatives of the market, we would be conceding to Friedman, vacating without contest the forums in which the invisible hand materializes in the bodies and actions of men and women. In that spirit, I have observed that wetland bankers do not tend to behave as if they were being puppetted by market forces, or seeking some demand-coordinating auctioneer, or even particularly interested in the market-clearing price. They are reflective, irrational, conflicted about their many possible roles, and apparently incapableeven if the institutions of the market allowed for perfect exchangeof arriving at Pareto-optimal outcomes. Four trends are evident in the practices by which entrepreneurial bankers set their credit prices; they are exemplified below, in excerpts from interviews conducted in 2001 and 2002.

\section{Don't Consider the Economic Situation of the Customer, or Even Negotiate over Prices}

MR: How do you set your prices?

S36: We do it by what the market will bear. 
MR: Just ask the customer?

S36: Well, we just set it ... we said $\$ 25,000$. They didn't baulk. And I figured, you know, the back of the envelope ... figured that we could do that and maybe make a little money ...

(Chicago banker ${ }^{15}$ )

The market-clearing calculus that is supposed to produce a price is nowhere apparent in this banker's account of setting a price. If the "discovery" of accurate price is composed of thousands of such moments, the Law of Large Numbers cannot help us since this banker is not using the "appropriate" criteria to set a price. Even the faintest interest in the capacity of a given client, or a class of clients, to pay a higher price would give the economist some scrap of hope for a Pareto-optimal outcome, but this banker was adamant that extensive negotiation over prices was extraneous to his business model. The back of his envelope contained no information about the economic situation of his customer, instead containing an entirely one-sided calculus concerning his own economy: what price would clear him a reasonable profit? The customer "not baulking" is the only moment of negotiation. Such asymmetry is quite common in many markets (think of the lack of negotiation over prices next time you visit the grocery store), but is still somewhat scandalous to neoclassical economic purists. Price discovery in the classical sense should proceed from this point until the customer does baulk, but the trade magazine Chicago Business noted without evident concern that this is not the standard practice in the banking industry: "Wetlands Initiative Senior Vice President Donald Hey says developers don't negotiate the price per credit. 'Nobody has asked for a reduction,' he says" (Murphy 2002).

\section{Consider Extra-economic Factors in Setting Price}

MR: So how do you come up with a price?

S40: Yeah, initially we looked at our costs, and what we anticipated our long-term costs would be, and arrived at a price that way.

MR: Would you consider the means of the customer?

S40: Yeah, I mean, you know, you kind of get a soft spot for some of those people, you know ... I just felt so sorry for that lady, I couldn't believe it.

(Minnesota banker ${ }^{16}$ )

There are two significant departures from the two theorems of welfare economics encapsulated here. Once again, this banker is setting his price with reference mainly to his cost of production rather than 
the ability of the customer to pay for the commodity. But in this case, while not considering economic means of the customer, he is clearly and strongly influenced by the distressing predicament of a client. The case involved a dairy farmer who had been "turned in" to the federal regulators by recreational hunters for filling in a small section of wetland, building a road to allow her cows to access land where the hunters preferred to shoot. The state issued a cease-and-desist order, ordered the road removed, and required that the farmer purchase wetland credits as compensatory mitigation. The wetland banker, a dairy farmer himself, was strongly influenced to offer a very low price both by feelings of solidarity against the state and by a degree of class antagonism against leisure hunters. These factors go considerably beyond the individual interest-based calculus of homo economicus.

\section{Conduct No Market Research}

MR: How did you arrive at 30 cents a square foot?

S9: I get calls, and some character called me from up by Thief River Falls and wants a price, and-you know, what the hell, you can't tell him that its 18,000 dollars an acre. So, I mean, you'd visit with 'em, and that's how I did my research, when people called me.

\section{(Minnesota banker ${ }^{17}$ )}

The active, agent-led moment in price discovery, if there can be said to be one in the classical formulation, might occur in efforts at market research. Commodity producers attempting to trim their production scheme to the winds of consumer preference and trends in price typically spend some effort in finding out what their commodity is trading for in neighboring markets, or what other producers are charging. While the banker above, unlike the previous examples, does engage in negotiation over price, he is not atypical in his impatience with these activities. This is probably because he, like many other bankers throughout the country, conducts his business as an adjunct to his primary occupation of residential development. Although there are no data on this matter, it is clear that many entrepreneurial bankers do not draw all of their income from credit sales, and many probably do not consider themselves to be "bankers" primarily or at all. This makes their individual identity in a market, and their collective identity as a fraction of capital, uncertain to say the least. If a banker's action in a market is not informed by their self-identification as a producer of wetland credits, it becomes entirely unclear which actions qualify as rational and which don't. Welfare economics has no concepts to deal with such complicated notions of agency. 


\section{Take Opportunities to Collude}

MR: How will you set a price?

S26: Oh ... I have a friend of mine that's doing the same thing, and he kind of found out from me or he knew about it, so he's doing it too. Yeah, he's a neighbor ... So we get together, we go golfing once in a while and stuff. But he's doing it too, and we have kind of a gentleman's agreement, we come up with a price.

\section{(Minnesota banker ${ }^{18}$ )}

This kind of casual anti-competitive behavior goes hand-in-hand with the general lack of concern for maximizing (rather than simply attaining) profit. Market participants seem to prioritize ensuring stability across a broader set of social relations, within which the wetland credit market exists alongside other concerns. Social bonds that go far beyond the transaction are vital in wetland credit trading not only in situations where the producer's identity overflows the category of "banker", as we have seen, but also in more conventional scenarios of agency. One banker, who conducts his business as his sole source of revenue, expresses clearly that competition is less a matter of price than of the cultivation of networks:

I know a large share of the development community, I know them well, and so I've been able to put together more deals than [I might have]. If one does not have such affiliations with people, and all you're trying to do is compete on price or whatever, that hasn't proved to be as beneficial. (Entrepreneurial banker ${ }^{19}$ )

I have suggested elsewhere (Robertson 2006) that the wetland banking industry is one in which prioritizing the maintenance of social networks over profit maximization is adaptive in the face of dramatic instability in the regulatory conditions which create demand. Regulatory changes at many scales, entirely exogenous to the market, can have a dramatic effect on production strategy (Robertson 2004); in such a situation, maintaining a flexible entrepreneurial strategy means tending to the social connections which can keep a banker afloat in steep seas rather than expending resources in a quixotic pursuit of the best possible price. This leaves us with a question that can have thunderous implications for neoliberal strategy, if taken seriously: what do "price signals" signal when market participants act in a way informed by any one, if not all four, of the complicating factors above?

But I do not wish to overstate the case. The above excerpts are not meant to imply that there are no bankers who negotiate extensively over prices, conduct market research, forego collusion or retain a professional disinterest in the personal lives of clients. Recognizable forms of negotiation over price, good-faith attempts to balance the utilities of producer and customer, in fact, happen every day in this market. But, as in this 
extended excerpt, they tend to affirm the pervasive role of regulatory force in shaping individual utility functions:

If I sat down with a builder and said, "look, it's gonna cost you 250 thousand dollars to buy credits from me", and he says, "Jeez, you know, my engineer says I can [build a wetland myself] for 200 thousand" I said, "Look. Ninety days from now, you're gonna have paid me 250 thousand in full, you're gonna get a letter from the Corps of Engineers, South Florida Water Management District, and Broward County Department of Environmental Protection saying that you never have to worry about this again. Your engineer thinks it's gonna cost 200 thousand including the value of the land". I said, "You know and I know ... that you have a five-year obligation, you have to hire a contractor to do the work, things don't always go as planned; in five years, you may have to remediate once or twice or three times. You're on the hook, you may have to put a bond up". I said, "Is it worth 50 thousand dollars to have this contingent liability, and you haven't even started to build this wetland yet, versus ninety days from now, writing me a check and forgetting about it forever?" It wound up being a good sales tool. (Florida banker ${ }^{20}$ )

The point of this section is not to suggest that wetland banking is fundamentally different than other commodity markets-although this argument can certainly be made. Rather it is to observe that price discovery is always a task achieved by complex agents whose identities exceed the economic, embedded in networks that extend beyond the breadth of the wetland credit market. This complexity cannot be wished or theorized away; it can only be undone by the conscious choices of agents who choose - contingently - to behave in economically rational ways. I have observed that bankers often seek stability within these larger networks, rather than maximizing their transaction-by-transaction profit. Setting price is only one of many, many decisions they have to make about achieving financial stability and other forms of non-economic satisfaction, decisions made more numerous because often the banker's economic identity is not firmly that of "producer of credits". Complex identities create complex price calculations, and price signals that are simply uninterpretable within the assumptions of neoliberal economics.

Neoliberal economists recognize this, to a certain degree. To the extent that they recognize agency as relevant at all, their impulse is usually to colonize these elements of noneconomic difference within market participants' identities by drawing such decisions within the realm of economic calculus. Rabin (1998:13) begins with admirable candor, that "[I]t is sometimes misleading to conceptualize people as attempting to maximize a coherent, stable, and accurately perceived $U(x)$ ", but thenin a rhetorical move similar to Shabman's graphical one in Figure 1-he returns to the arms of economic dogma: "economists ought to become 
aware of the shortcomings of our models, regret these shortcomings, and keep our eyes open for ways to remedy them". These arguments always end up in deeply functionalist places, and when presented with unmodelable departures from homo economicus, economists may become rather impatient:

Claims about that evidence inconsistent with our traditional model of human behavior can be neglected because the evidence derives from observations of people insufficiently motivated to behave themselves according to economic assumptions, or because it fails to bear sufficiently great burdens of proof, or because the implied behavior is unlikely to matter in the types of (market) settings that economists care about. (Rabin 1998:41)

Resource economists have long lamented that the lack of actual markets in ecosystem services such as clean water and wetlands biodiversity means that their estimation of the value of these services must rely on methods of dubious reliability such as "willingness-to-pay" surveys or hedonic analysis. The arrival of actual markets heralds the generation of "straightforward, readily estimable values" in the form of price (Turner et al. 2003, 497). This is seen to be somewhat less tidy in practice, as market actors refuse to be confined within market-rational conceptions of agency, and price is thus heavily overdetermined.

\section{Consequences for Market Environmentalism}

I don't see anything in Water Quality Trading that I don't have something in my [economic theory] bag to pull out and address it with. (Economist Tony Prato ${ }^{21}$ )

While neoliberal economists tend to view market dynamics without seeing the people who create those dynamics, critics of neoliberalism should not make the same mistake. Too often, resistance to neoliberal strategy is theorized as contingent, rich with diverse agency, and fruitfully multivocal, while the forces that advance neoliberal strategy are described in agency-flattening and even structural terms. The people who strive to create new markets after the principles of neoliberal economics are given a difficult task, and the potential regulators, consumers, and producers of new kinds of commodities are given little practical guidance in resolving some of the key obstacles. What they are given, and which must not be discounted, is the benevolent embrace of the state, promises of subsidy and research, and warm assurances by political figures that they are "part of the army of citizen conservationists" 22 who will lead this nation out of the morass of 1970s environmental policy errors into a neoliberal utopia. But these same leaders steadfastly refuse to lead, constantly invoking governance over government: "You are the experts!"23 
conjures one to an audience of prospective entrepreneurs, and another desires only to "comport ... with the changes that have already taken place in the hearts and minds of the American people". ${ }^{24}$ In places, the "neoliberal rollout" (Peck and Tickell 2002) looks as fractured and uncoordinated as resistance to it, with market actors' identities exceeding the economic, state fractions tripping over themselves, and economists producing policy prescriptions that make entrepreneurial practitioners gnash their teeth in frustration. This can largely be traced back to the fact that, while neoliberal policy must be enacted by particular agents in specific locations, neoliberalism in its purer forms declines to theorize either agency or location.

Understanding the close texture of individual neoliberal capitalist strategies reveals not only that are there ample openings for resistance and redirection, but that rollout and resistance may be embodied in the same policy and in fact the same person. All of the attendees at the WQT forums were active, and for the most part enthusiastic, participants in the creation of new neoliberal economic forms, and yet there was a good deal of open conflict on the specifics of market design, conflict that continues to threaten the integrity of the entire policy initiative and to which few effective responses are offered. Economists, when asked for specific information on how best to set price or stimulate production, respond unhelpfully with Say's Law, the Law of Large Numbers, and other abstractions in the form of normative fables. Prato's epigram above is one such fable: WQT and wetland banking are not new under the sun, and require no retooling of the basics of neoliberal economic policy. The state tells a parallel fable: the privatization of nature is going to interpellate all of us as producers or consumers in a marketplace of ideas, services, and other commodities. As the state informed us at the opening session of a recent national conference on water quality trading: "No matter where you said you're from when you stood up for the roll call this morning, you're in here as business innovators". 25

The emptiness of these fables is dangerous, because under neoliberal capitalism we have accepted the role of price as a principal guarantor of democracy. Liberal economics was (and is) embraced politically not only because it advanced capitalism, but because it promised a way to replace the visible violence of political struggle with the invisible violence of economic struggle, to reduce differences to preferences (Harvey 1990; Lefebvre [1974] 1991:396). If people can be rendered as different only in our utility functions, then these differences can be reconciled in a market rather than a battlefield. This is the political context in which, increasingly, "democratic choice" has been defined as "choice in a market", an arrangement that makes a price mechanism working smoothly enough to reach Pareto-optimality the guarantor of democracy. Evidence that the price mechanism fails to operate as desired strikes at the heart of the 
political rationale for neoliberalism and points towards neoliberalism's failure on its own terms.

In short, price in emerging markets for poorly defined commodities doesn't work the way neoliberal theory needs it to in order to deliver on its promise of market-led democracy. As we are evidently in a period of market expansion into new kinds of property and commodities, such situations may be assumed to be relatively common, and we should pay particular attention to the justification of initiatives to commodify "ecosystem services" such as clean air and biodiversity. Were economists not impervious to a world of countervailing data, this should be disturbing to them; but while doing this kind of ground-truthing on neoliberal claims is valuable, it is not going to convince economists insulated by Friedman's methodology. They will never be the audience that matters; efforts to fact-check neoliberal claims are much more potent when inserted directly into the political and policy realm. A little grey geography goes a long way (Peck 1999) when economists have ceded the field of providing specific answers and suggestions instead of laws. It can be very effective to produce answers that recognize the actual conditions under which entrepreneurs and consumers make decisions, using venues and language likely to engage rather than repel their interest (Robertson 2006 is one very modest attempt). It can also be illustrative to demonstrate the emptiness of welfare economic precepts, eg by pushing them to $\mathrm{ad}$ absurdum limits in the context of stakeholder forums. Such work requires that we understand the agents of neoliberal capitalism as complex and conflicted identities rather than as automatons.

On the ground, price discovery and commodity identities are results of people muddling through, and these producers, consumers and regulators are seeking guidance:

Sociology enters the equation in the problem of how actors produce a social world stable enough that they can sell those goods and services at a price at which the organization will survive. Managing people and uncertain environments to produce stability is a sizable task. Those who do it every day often demonstrate great skill and creativity as they lurch from crisis to crisis. (Fligstein 2001:18)

Neoliberal theorists are necessarily blind to many of the spaces where such issues are hammered out; I have only gestured at the deep tripartite disconnect between economic theorists, neoliberal policy advocates, and actual entrepreneurs on how neoliberal capitalism should be rolled out. Some of the people muddling through are in farm fields in Minnesota, some work at sewage treatment plants in Durango, and some are in think tanks in Washington DC. They are waiting for answers that critical geographers can provide. What is the commodity? How do we set price? The answers they get can help advance neoliberal strategy, redirect it, or drive it toward the rocks of its own contradictions. 


\section{Acknowledgements}

I am grateful for the extremely helpful comments of Joel Wainwright, Dan Bromley, Jamie Peck, Nik Heynen and two anonymous reviewers, although all errors remain my own. This paper was completed with support from a Doctoral Dissertation Research Improvement Grant from the NSF, a Dissertation Writing Fellowship from the University of Wisconsin, and a fellowship from the Oak Ridge Institute for Science and Education. The views represented in this paper are the author's alone and do not necessarily represent those of the Environmental Protection Agency.

\section{Endnotes}

${ }^{1}$ Daniel Bromley, University of Wisconsin Department of Agricultural and Applied Economics, personal communication, May 2000. See also his book Sufficient Reason (2006).

${ }^{2}$ Dennis King, University of Maryland Department of Economics, 7 November 2005, speaking at the National Forum on Synergies Between Water Quality Trading and Wetland Mitigation Banking, Carnegie Endowment for International Peace, Washington, DC. The proceedings are detailed in ELI (2005).

${ }^{3}$ The two theorems state, in short, that (1) markets in competitive equilibrium produce optimal social welfare (ie Pareto-optimality), and (2) any initial distribution of resources can lead to equilibrium.

${ }^{4}$ When I discuss Say's Law, it is not with the intention of erecting a straw man. A normalscience reading of economics regards Say's Law as irrelevant: students of demand-side economics were taught that the Law was superseded by Keynesianism, and students of supply-side economics were taught that it was superseded by the Arrow-Debreu proof. These traditions aside, what concerns me here is that the Law itself is still cited authoritatively in the actual forums in which decisions are made concerning how to construct markets.

${ }^{5}$ I use "mainstream economics" in a way that overlaps with "neoclassical economics" or "classical liberal economics" to indicate the utility-based methodologically individualist approach to economics that has become so hegemonic in the United States since World War II that it can barely conceive of coherent opposition to its precepts.

6 "Point-source" and "non-point-source" pollution in water are legal terms of art: any discrete conveyance that can be said to resemble a pipe, delivering concentrated effluent, is regulated under Section 302 of the CWA. The diffuse entry of pollutants (say, from farm-field runoff) is not (Findley and Farber 1999:375).

${ }^{7}$ Susan Burke, Idaho Department of Environmental Quality, at the Second National Water Quality Trading Conference, Pittsburgh, PA, 24 May 2006.

${ }^{8}$ Tony Prato, University of Missouri Department of Economics, comment at the US EPA Research Planning Conference on Wetlands and Water Quality Trading, 16 February 2006, Chicago, IL. The proceedings are detailed in EPA ORD (forthcoming).

9 James Shortle, Pennsylvania State University Department of Agricultural Economics, comment at the Second National Water Quality Trading Conference, 23 May 2006, Pittsburgh, PA.

10 The South Nation Conservancy website encourages landowners to apply for SNC's grants program as a source of funding for projects which will improve water quality. However, the site does not reveal that the SNC accumulates "water quality credits" thereby, which will be purchased by polluters: http://www.nation. on.ca/English/CleanWater.htm. 
${ }^{11} \mathrm{http} / / /$ www.miamiconservancy.org/water/quality_credit.asp

${ }^{12}$ Dennis King, University of Maryland Department of Economics, 11 July 2005, speaking at the National Forum on Synergies Between Water Quality Trading and Wetland Mitigation Banking, Carnegie Endowment for International Peace, Washington, DC. The proceedings are detailed in ELI 2005. The Law of Large Numbers, in its weak form, states that given an infinite sequence of uncorrelated random variables, where all have the same expected value and variance, the sample average will tend to converge on the expected value. King's use was inappropriate because it assumes identical expected values and variance for all BMP implementations.

${ }^{13}$ The positions in this paragraph paraphrase a three-way discussion between Iowa State University ecologist William Crumpton, University of Missouri economist Tony Prato, and EPA staffer Sue Elston at the 2006 Chicago forum.

14 The Hon Bruce Knight, chief of USDA's Natural Resource Conservation Service, 25 May 2006, speaking at the Second National Water Quality Trading Conference, Pittsburgh, PA.

${ }^{15}$ Interview conducted 4 December 2002.

${ }^{16}$ Interview conducted 7 November 2002. While many Minnesota bankers are nonentrepreneurial in their identity as wetland bankers, and the banking community nationwide tends to dismiss Minnesota on this ground, this interviewee is thoroughly entrepreneurial in his approach and has participated in moderately successful attempts to organize Minnesota wetland bankers into a self-identified fraction of capital.

${ }^{17}$ Interview conducted 19 July 2001.

${ }^{18}$ Interview conducted 12 February 2003.

${ }^{19}$ Interview conducted 25 July 2001.

${ }^{20}$ Interview conducted 27 February 2002.

${ }^{21}$ Tony Prato, University of Missouri Department of Economics, comment at the US EPA Research Planning Conference on Wetlands and Water Quality Trading, 16 February 2006, Chicago, IL. The proceedings are detailed in EPA ORD (forthcoming).

22 The Hon George Dunlop, Deputy Assistant Secretary of the Army for Civil Works, 26 April 2006, speaking at the Ninth National Mitigation and Conservation Banking Conference, Portland, OR. Dunlop is the political appointee in charge of the regulatory branch of the US Army Corps of Engineers.

${ }^{23}$ Brent Fewell, USEPA Deputy Assistant Administrator for Water, 25 May 2006, speaking at the Second National Water Quality Trading Conference, Pittsburgh, PA.

${ }^{24}$ The Hon George Dunlop, Deputy Assistant Secretary of the Army for Civil Works, 26 April 2006, speaking at the Ninth National Mitigation and Conservation Banking Conference, Portland, OR.

${ }^{25}$ Bryon Griffith, chief of the US EPA Gulf of Mexico Program, 23 May 2006, speaking at the Second National Water Quality Trading Conference, Pittsburgh, PA.

\section{References}

Amin A and Thrift N (1995) Institutional issues for the European regions: From markets and plans to socioeconomics and powers of association. Economy and Society 24(1):41-66

Bakker K (2005) Neoliberalizing nature? Market environmentalism in water supply in England and Wales. Annals of the Association of American Geographers 95(3):542565

Boyer R (1997) The variety and unequal performance of really existing markets: Farewell to Doctor Pangloss? In J R Hollingsworth and R Boyer (eds) Contemporary Capitalism: The Embeddedness of Institutions (pp 55-93). Cambridge: Cambridge University Press 
Bromley D (2006) Sufficient Reason: Volitional Pragmatism and the Meaning of Economic Institutions. Princeton, NJ: Princeton University Press

Castree N (1995) The nature of produced nature: Materiality and knowledge construction in Marxism. Antipode 27(1):12-48

Castree N (2002) False antitheses? Marxism, nature and actor-networks. Antipode 34(1):111-146

Costanza R, d'Arge R, de Groot R, Farber S, Grasso M, Hannon B, Limburg K, Naeem S, O'Neill R V, Paruelo J, Raskin R G, Sutton P and van den Belt M (1997) The value of the world's ecosystem services and natural capital. Science 387(6630):253-260

Daily G C (1997) Introduction: What are ecosystem services? In G C Daily (ed) Nature's Services: Societal Dependence on Natural Ecosystems (pp 1-10). Washington, DC: Island Press

Daily G C and Ellison K (2002) The New Economy of Nature: The Quest to Make Conservation Profitable. Washington, DC: Island Press

Dales J H (1968) Land, water, and ownership. Canadian Journal of Economics 1(4):791804

Environmental Law Institute (ELI) (2002) Banks and Fees: The Status of Off-Site Wetland Mitigation in the United States. Washington, DC: Environmental Law Institute

Environmental Law Institute (ELI) (2005) National Forum on Synergies Between Water Quality Trading and Wetland Mitigation Banking: Forum Report. Washington: ELI

Environmental Protection Agency (EPA) (2003) Final water quality trading policy, 13 January, http://www.epa.gov/owow/watershed/trading/finalpolicy2003.html

Environmental Protection Agency (EPA) (2005) Mitigation banking factsheet, 28 November, http://www.epa.gov/owow/wetlands/facts/fact16.html

Environmental Protection Agency (EPA) and United States Department of Agriculture (USDA) (2006) Partnership agreement between the United States Department of Agriculture Natural Resources Conservation Service and the United States Environment Protection Agency Office of Water, signed 13 October, http://www.epa.gov/owow/ watershed/trading/mou061013.pdf

Environmental Protection Agency Economic Incentives Task Force (EPA EITF) (1991) Economic Incentives: Options for Environmental Protection, March. Washington, DC: USEPA

Environmental Protection Agency Office of Research and Development (EPA ORD) (forthcoming) Proceedings of US EPA Research Planning Conference on the Role of Wetlands in Water Quality Trading

Findley R W and Farber D A (1999) Cases and Materials on Environmental Law. 5th ed. St Paul, MN: West Group

Fligstein N (2001) The Architecture of Markets: An Economic Sociology of Twenty-first Century Capitalist Societies. Princeton, NJ: Princeton University Press

Gibson-Graham J K (1993) Waiting for the revolution, or how to smash capitalism while working at home in your spare time. Rethinking Marxism 6(2):10-24

Hahn R W (1983) Designing markets in transferable property rights: A practitioner's guide. In E F Joeres and M H David (eds) Buying a Better Environment: Cost-effective Regulation through Permit Trading (pp 83-97). Madison, WI: University of Wisconsin Press

Harvey D (1990) The Condition of Postmodernity: An Enquiry into the Origins of Cultural Change. Cambridge, MA: Blackwell

Hodgson G (1988) Economics and Institutions. Cambridge: Polity Press

Huber P W (1999) Hard Green: Saving the Environment from the Environmentalists. New York: Basic Books

King D M and Herbert L W (1997) The fungibility of wetlands. National Wetlands Newsletter 19(5):10-13 
King D M and Kuch P (2003) Will nutrient credit trading ever work? An assessment of supply problems, demand problems, and institutional obstacles. Environmental Law Reporter 33:10352-10368

Lefebvre H ([1974] 1991) The Production of Space. Cambridge, MA: Blackwell

Mäki U (2000) Kinds of assumptions and their truth: Shaking an untwisted F-twist. Kyklos 53(3):317-335

McAfee K (1999) Selling nature to save it? Biodiversity and green developmentalism. Environment and Planning D: Society and Space 17:133-154

McAfee K (2003) Neoliberalism on the molecular scale. Economic and genetic reductionism in biotechnology battles. Geoforum 34:203-219

Mirowski P (2001) Machine Dreams: Economics Becomes a Cyborg Science. Cambridge: Cambridge University Press

Murphy H L (2002) Wetlands no longer soak plans for many builders. Crain's Chicago Business 23 September

National Research Council (NRC) (2001) Compensating for Wetland Losses under the Clean Water Act. Washington, DC: National Academy Press

National Research Council (NRC) (2005) Valuing Ecosystem Services: Toward Better Environmental Decision-making. Washington, DC: National Academy Press

Oates WE (2006) An economic perspective on environmental and resource management: An introduction. In W E Oates (ed) The RFF Reader in Environmental and Resource Policy (pp xv-xx). Washington, DC: Resources for the Future

O'Connor J (1994) Is sustainable capitalism possible? In M O'Connor (ed) Is Capitalism Sustainable?: Political Economy and the Politics of Ecology (pp 152-175). New York: Guilford

O'Connor M (1994) On the misadventures of capitalist nature. In M O'Connor (ed) Is Capitalism Sustainable? Political Economy and the Politics of Ecology (pp 125-151). New York: Guilford

Peck J A (1999) Editorial: Grey geography? Transactions of the Institute of British Geographers, New Series 24:131-135

Peck J A and Tickell A (2002) Neoliberalizing space. Antipode 34(3):380-404

Polanyi K (1944) The Great Transformation: The Political and Economic Origins of Our Time. Boston: Beacon Press

Rabin M (1998) Psychology and economics. Journal of Economic Literature 36: $11-46$

Robertson M M (2004) The neoliberalization of ecosystem services: Wetland mitigation banking and problems in environmental governance. Geoforum 35: 361-373

Robertson M M (2006) Emerging ecosystem service markets: Trends in a decade of entrepreneurial wetland banking. Frontiers in Ecology and Environmental Science 4(6):297-302

Rolband M S, Redmond A and Kelsch T (2000) Wetland mitigation banking. In D M Kent (ed) Applied Wetland Science and Technology (pp 181-213). Boca Raton, FL: CRC Press

Rosenberg A (1992) Economics: Mathematical Politics or Science of Diminishing Returns? Chicago: University of Chicago Press

Scodari P and Shabman L A (1995) National Wetland Mitigation Banking Study: Commercial Wetland Mitigation Credit Markets: Theory and Practice. US Army Corps of Engineers Institute for Water Resources Report IWR 94-WMB-7. Alexandria, VA: USCOE IWR

Shabman L A and Batie S S (1980) Estimating the economic value of coastal wetlands: Conceptual issues and research needs. In V S Kennedy (ed) Estuarine Perspectives (pp 3-15). New York: Academic Press 
Shabman L A, Scodari P and King D M (1994) National Wetland Mitigation Banking Study: Expanding Opportunities for Successful Mitigation: The Private Credit Market Alternative. US Army Corps of Engineers Institute for Water Resources Report IWR 94-WMB-3. Alexandria, VA: USCOE IWR

Shabman L A, Scodari P and King D (1996) Wetland mitigation banking markets. In L L Marsh, D R Porter and D A Salvesen (eds) Mitigation Banking: Theory and Practice (pp 109-138). Washington, DC: Island Press

Sibbing J (2005) Mitigation banking: Will the myth ever die? National Wetlands Newsletter 27(6):5-6, 8

Society of Wetland Scientists (SWS) (2005) Wetland mitigation banking. http://www. sws.org/wetlandconcerns/banking.htm

Turner R K, Paavola J, Cooper P, Farber S, Jessamy V and Georgiou S (2003) Valuing nature: Lessons learned and future research directions. Ecological Economics 46:493510

US Army Corps of Engineers (USACOE), US Environmental Protection Agency, US Fish and Wildlife Service, Natural Resource Conservation Service, and National Oceanic and Atmospheric Administration (1995) Federal guidance for the establishment, use and operation of mitigation banks. Federal Register 60(228):58605-58614

US Army Corps of Engineers (USACOE) and Environmental Protection Agency (EPA) (2006) Compensatory mitigation for losses of aquatic resources: Proposed rule. Federal Register 71(59):15520-15556

Watts M (1994) Development II: The privatization of everything? Progress in Human Geography 18(3):371-384

White House Office on Environmental Policy (WHOEP) (1993) Protecting America's Wetlands: A Fair, Flexible and Effective Approach. Washington, DC: The White House Zagata M D (1992) Mitigation banking: Creating a win/win situation. In J A Kusler and C Lassonde (eds) Effective Mitigation: Mitigation Banks and Joint Projects in the Context of Wetland Mitigation Plans (pp 61-63). Berne, NY: ASWM 